\title{
Współczesna proza z „kocimi” bohaterami w kontekście uwrażliwiania dziecka na drugiego człowieka
}

\begin{abstract}
STRESZCZENIE
Celem artykułu jest propozycja wykorzystania w edukacji dziecka książek dysponujących potencjałem uwrażliwiania na drugiego człowieka (często „Innego”), budowania z nim więzi, poszukiwania emocjonalnej wspólnoty doświadczeń. W interesującej mnie wybranej najnowszej polskiej prozie dla dzieci (mam tu na myśli literaturę dla dzieci ostatnich dwóch dekad, a więc po 2000 roku), którą poddałam analizie, zauważyłam kociego bohatera występującego zdecydowanie często w kontekście problematyki odmienności społeczno-kulturowej. Postać kota w analizowanych testach została wykorzystana do praktycznych celów, stała się poetyckim chwytem budzącym pozytywne skojarzenia, sprzyjającym kształtowaniu u dzieci wartości i uczuć wyższych. W książkach zauważam odniesienia do założeń edukacji międzykulturowej, stąd uważam, że mogą one stanowić pomoc rodzicom, nauczycielom i wychowawcom w przygotowaniu dziecka do spotkania z Innym, do koegzystowania, współpracy z nim, koleżeństwa czy przyjaźni. Książki ukazują różne oblicza dzieciństwa, dziecięce dramaty przeżywane przez rówieśników w różnych częściach świata, groźne aspekty wojny, problemy imigracji i migrantów.
\end{abstract}

\section{Słowa kluczowe:}

literatura dla dzieci, dziecko, kot jako bohater literacki, uwrażliwianie kulturowe, edukacja międzykulturowa, „Inny”

1 Anna Józefowicz, Wydział Pedagogiki i Psychologii, Uniwersytet w Białymstoku, Polska, e-mail: a.jozefowicz@uwb.edu.pl, ORCID ID: https://orcid.org/0000-0001-9126-3874. 


\begin{abstract}
The aim of the article is to use books in a child's education that have the potential to sensitize the other person (often the "Other”), build relationships with the "Other", searching for an emotional community of experiences. In the selected one, interesting to me, the latest Polish prose for children (I mean literature after 2000), which I have analyzed, I noticed cat's hero occurring very often in the context of the issue of socio-cultural diversity. In the analyzed tests, cat figure, has been used for practical purposes, has become poetic grip evoking positive associations, conducive to shaping values and higher feelings in children. In books I notice references to the assumptions of intercultural education, hence I think that they can help parents, teachers, educators in preparing the child for meeting the Other, to co-exist, cooperate with him/her, to companionship or friendship. Books show different faces of childhood, children's dramas experienced by peers in different parts of the world, dangerous aspects of the war, problems of immigration and migrants.
\end{abstract}

\title{
Keywords:
}

literature for children, child, cat as a literary figure, cultural sensitivity, intercultural education, ,Other”

\section{PIERWSZE KOTY ZA... MIAST WSTĘPU}

Kulturowe dzieje kota sięgają Starożytnego Egiptu, kiedy to około 2000 roku p.n.e. został on udomowiony i jednocześnie obdarzony szczególną czcią. Nigdy potem nie cieszył się aż taką estymą. Poświęcony był wtedy bogini Bastet, którą przedstawiono pod postacią kotki bądź kobiety z głową kota i utożsamiany z płodnością, szczęściem, ciepłem słonecznym. Ponieważ był zwierzęciem świętym, zakazane było jego zabijanie, a po śmierci jego zwłoki były mumifikowane (J.C. Cooper, 1998, s. 118).

Jak twierdzi Władysław Kopaliński, starożytni Egipcjanie wierzyli, że zwierzęta te broniły matki oraz ich dzieci przed demonami (Kopaliński, 1990, s. 164). Na terenie Skandynawii koty były atrybutem Freyi - bogini miłości, ale i władczyni nocy. Dwa czarne koty ciągnęły jej rydwan. Kot związany był z księżycem, co czyniło go zwierzęciem lunatycznym, które widzi i poluje nocą, którego oczy błyszczą w ciemności. Był także atrybutem innych księżycowych bogiń: rzymskiej Izydy i greckiej Artemidy, które to same zmieniały się w kotki. Dla Indian amerykańskich dziki kot był bogiem łowcą, symbolem skrytości (Cooper, 1998, s.117). Kota postrzegano także jako mentora szamanów poddających się inicja- 
cji (Slany, 2009, s. 15-17). W mitach „kraju kwitnącej wiśni” kot utożsamiany był z chytrością oraz przemianą - umiejętnością zmiany postaci. Także wśród japońskich żeglarzy kot, zwłaszcza czarny, cieszył się powodzeniem. Wierzono, że posiada moc utrzymania złych demonów głębin z dala od statku, a także, że jest zwiastunem dobrej pogody. W Islamie to kot, w odróżnieniu od psa, którego muzułmanie uważają za zwierzę nieczyste, został błogosławiony przez Proroka. Z kolei w dawnej Polsce, jak przytacza Władysław Kopaliński, „,kot zajął miejsce oswojonej łasiczki i był chroniony obyczajem”, a kto zabił kota, zhańbił się, gdyż było to zajęcie hyclowskie (Kopaliński, 1985, s. 530-531). W kulturach muzułmańskiej i indyjskiej mówiło się, że kot został obdarzony 7 lub 9 żywotami, a w numerologii cyfry te oznaczają wieczność, stąd przekonanie o właściwościach magicznych kota. Znane jest także powiedzenie, że kot zawsze spada na 4 łapy.

Na powyższych wierzeniach kończy się kulturowe „błogosławieństwo” kota, nadchodzą bowiem czasy chrześcijaństwa, a owa religia, zwłaszcza w średniowiecznej Europie, wiązała kota z siłami nieczystymi, czarną magią, diabłem, siłą wiedźm. Kot jako zwierzę noce, lunarne, uważany był za symbol: grzechu, czarów, zła, nieszczęścia, śmierci, chytrości, zdrady, pochlebstwa, egoizmu, niewierności, dumy, niezależności, swobody, lenistwa. To tylko niektóre wyobrażenia dotyczące kota wymienione przez Władysława Kopalińskiego w Słowniku symboli (Kopaliński, 1985, s. 161-162). Być może owa kocia niezależność, nieodgadniona, trudna do okiełznania natura, dystans, skontrastowane z psią wiernością, przywiązaniem, przyczyniły się do uczynienia z niego na całe wieki średnie synonimu fałszu i obłudy. Kocie oczy, pozostające w nieustannym ruchu, zwężające się i rozciągające, budziły kontrowersje, a jego chód kojarzony był z ukradkowością, skrytością. Toteż nie rozumiano go, unikano, bano się. W tradycji celtyckiej kot łączony był z siłami chtonicznymi, był zwierzęciem pogrzebowym i proroczym. Łączone z nim były również żywioły nadnaturalne, przez co miał ponoć zdolności parapsychiczne, potrafił przeczuć zbliżające się zagrożenie. Poza Europą w wierzeniach Chińczyków kot związany był z yin - siłami zła i przemiany, potrafił także zmieniać swą postać (Cooper, 1998, s. 117).

W folklorze większości kultur uważa się kota, zaraz po lisie, za najbardziej chytre zwierzę. Wokół jego postaci nagromadziło się mnóstwo anegdot, przesądów, zabobonów, przysłów, w których kot jawi się jako postać demoniczna (np.: za zły omen uważano, kiedy kot przejdzie drogę), toteż figura kota na stałe weszła w krąg tematów związanych z magią, niesamowitością, transcendencją. Po dziś dzień pejoratywny stosunku do owego zwierzęcia przejawia się w powiedzonkach: „drzeć z kimś koty” (spierać się, kłócić), „kocia muzyka” (fałszywa), „przekręcać kota ogonem” (przedstawić coś w sposób wykrętny), „pierwsze koty za płoty” 
(pierwsze próby często kończą się niepowodzeniem), „,biega jak kot z pęcherzem” (wszędzie go pełno, nie może sobie znaleźć miejsca)².

Dopiero pod koniec Średniowiecza, a właściwie w czasach Renesansu, doceniono istnienie kota. Kiedy to w XIV wieku Europę dziesiątkowała czarna śmieć rozniesiona przez gryzonie, pomoc kotów okazała się wręcz nieoceniona. W tym miejscu można wymienić pozytywne walory przypisywane kotu: czystość, wdzięk, elegancję, grację, delikatność, długowieczność, płodność (Cooper, 1998, s. 119).

Omówiona powyżej szeroka symbolika kota świadczy o jego niezwykłości. Koci charakter, mówi się nawet kocia osobowość, były kuszące dla licznych twórców. Malarze, rzeźbiarze, twórcy filmów i animacji, a nade wszystko pisarze chętnie sięgają po „kocie motywy”. Koty zadomowiły się dawno temu w mitach, ludowych podaniach, baśniach i legendach. W literaturze światowej kota odnajdziemy zarówno w literaturze dla dzieci, jak i dorosłych.

Kto z nas nie zna kołysanki „A, a, a! kotki dwa...” albo zabawy z dzieciństwa w „Koci, koci łapci...” czy „Uciekaj myszko do dziury...”, jak również bajeczki o kocie, co palił fajkę? Nawet pierwsze zdanie w elementarzu brzmi „Ala ma kota” (Szary, 2009, s. 17). Każdy w dzieciństwie znał także piosenkę o kotku na płotku czy wierszyk zaczynający się od słów „W pokoiku na stoliku...”. W pamięć zapadały również wyraziste kocie sylwetki psotnego Filemona i piecucha Bonifacego z kreskówki Marka Nejmana. Dalej można wymieniać całą plejadę sprytnych kotów na czele z Kotem w Butach. Byłyby to koty z bajek La Fontaine’a (koty były w nich głównie ucieleśnieniem szelmostwa), kot chodzący własnymi drogami z opowiadania Rudyarda Kiplinga z 1902 roku czy Kot Mruczysław (wcielenie mędrca) z powieści E.T.A. Hoffmana. W powieści Lewisa Carrolla pojawia się „kot bez uśmiechu i uśmiech bez kota”, a więc Kot z Cheshire, znamienity gawędziarz i plotkarz, budzący zachwyt i oniemienie Alicji. Wielkim chytrusem, pozwalającym oderwać się poprzez swoje wybryki od „szarej, radzieckiej” rzeczywistości, był kot Behamot z powieści Bułhakowa. Odwrotnością charakterologiczną demonicznego

2 Powiedzenie, „biega jak kot z pęcherzem” przetrwało jako dokument barbarzyńskiej średniowiecznej praktyki, wiążącej się z wypędzaniem z kota diabła. Owa tradycja wiązała się z przywiązywaniem kotu do ogona pęcherza z grochem w środku. Kot, słysząc za sobą hałas, zaczynał biegać, jakby postradał zmysły. Takie praktyki (także męczenie kota poprzez zamykanie go w beczce i uderzanie w beczkę kijami, aż zostanie ona rozbita, co powodowało śmierć kota), są reliktem czasów karnawału epoki Średniowiecza, gdzie kot w tym czasie traktowany by jako zwierzę magiczne, a męczenie go traktowano jako gest groteskowy i rytualny. Bogata symbolika kota (m.in. kot jako zwierzę magiczne, opiekun, atrybut błazna) w różnych epokach historycznych i dziedzinach nauki, była tematem konferencji naukowej Słodkie kotki w Internecie? Kot w literaturze i kulturze (Siedlce, 8-9 VI 2017) organizowanej przez Instytut Kultury Regionalnej i Badań Literackich Franciszka Karpińskiego. 
Behamota był budzący szacunek, opanowany, inspirujący do podniosłych czynów, boski Aslan z Opowieści z Narnii.

Motyw kota w literaturze to wciąż potencjał niewyczerpany, jednakże we współczesnej literaturze dla dzieci zdecydowanie częściej spotykamy koty przyjazne, przymilne, bardziej leniwe niż demoniczne czy niedostępne. W interesującej mnie polskiej najnowszej prozie dla dzieci (mam tu na myśli literaturę dla dzieci ostatnich dwóch dekad, a więc po 2000 roku), którą poddałam analizie, zauważyłam kociego bohatera występującego często w kontekście problematyki odmienności społeczno-kulturowej, podejmowanych prób uwrażliwiania na losy drugiego człowieka (często „Innego”). W powieściach Kot Karima i obrazki Lilianny Bardijewskiej. I Kot, który zgubił dom Ewy Nowak występują koci uchodźcy. Powieść Joanny Rudniańskiej Kotka Brygidy (2007) opowiada o II wojnie światowej z perspektywy dziecka, gdzie kotka należąca do żydowskiej dziewczynki pozwala na ocalenie o niej pamięci.

Wartość analizowanych lektur zasadza się na otwieraniu swoją fabułą dróg do refleksyjności na temat wewnętrznego świata przeżyć drugiej osoby, na przykładzie losów bohaterów ukazywane są próby zrozumienia siebie i innych, poszukiwania wspólnoty doświadczeń. W mojej opinii korzystanie z paradygmatu „współistnienia”, na którym opiera się koncepcja edukacji międzykulturowej, stanowić może klucz do interpretacji opowieści. Edukacja międzykulturowa, promując paradygmat „współistnienia”, zakłada możliwość wzajemnego rozwoju w wyniku porozumienia, negocjacji, kooperacji, przywraca wiarę w człowieka, w jego moc wewnętrzną i wrażliwość na potrzeby innych (Nikitorowicz, 2005, s. 216-218).

Ponadto, książki z bohaterami zwierzęcymi łatwiej trafiają do dziecięcego odbiorcy, gdzie postać słodkiego, mięciutkiego zwierzaka ma wzruszyć bądź zabawić na pewno nie pozwoli przejść obok niego obojętnie. Jean Piaget w swojej pracy Jak sobie dziecko wyobraża świat, wyjaśniał, jak wyjątkowa jest dziecięca wrażliwość na świat, jak dziecko jest w stanie zauważać jego piękno, jak silne jest dziecięce odczuwanie przynależności, więzi z wszechświatem, jak potrafi ono ów wszechświat ożywić i jak w jego naturze leży pogodny stosunek do zwierząt (Piaget, 2006, s. 37). Alicja Baluch stwierdziła z kolei, że kot jest to „,[... ] zwierzątko najbardziej odpowiadające emocjonalnym, ludycznym i poznawczym potrzebom dziecka. Każde dziecko wie, że kot jest miękki i można go głaskać, ma ogon i da się go za ogon łapać, miauczy i nietrudno go naśladowanie, mruczy- usypiająco [...]. Pije mleko, co każdy rozumie, łapie myszki, a to jest fascynujące. Dlatego 
też ta wyrazista postać kota nadaje się do roli bohatera literackiego. Jego obraz jest łatwy do konkretyzacji i interpretacji” (Baluch, 2009, s. 5).

\section{KOCI UCHODŹCY - UWRAŻLIWIANIE NA KRZYWDĘ DRUGIEGO CZŁOWIEKA}

Historie z książek Ewy Nowak Kot, który zgubił dom (2016) oraz Lilianny Bardijewskiej Kot Karima (2016) poruszają aktualny temat wojny na Bliskim Wschodzie, losy imigrantów uciekających do Europy, utratę domu i ukochanych osób. Powieści można osadzić w problematyce dotyczącej Inności, dialogu, tolerancji, gdzie tolerancję dobrze jest rozumieć jako „wychodzenie na pogranicza świadomościowe, kulturowe, zdobywanie się na uznawanie Inności, która niekiedy może być przykra, ale też inspirująca i twórcza” (Nikitorowicz, 2005, s. 218). Ponadto warto zaakcentować, iż Kot Karima wchodzi w skład serii o wymownym tytule Wojny Dorosłych - Historie Dzieci ${ }^{3}$, serii prezentującej historie oparte na faktach, którą to można określić literaturą zaangażowaną lub „literaturą antropologicznie wrażliwą"4.

Stąd też zadaniem edukacji jest przeciwdziałanie dyskryminacji ze wzglądu na inność, tak więc przygotowywanie dziecka do odkrywania i rozumienia Innego, zaczynając od dostrzegania go w sobie (Nikitorowicz, 2005, s. 109).

Analizowane książki adresowane są do dzieci w młodszym wieku szkolnym. Dzieci w tej wyjątkowo wrażliwej fazie rozwojowej dysponują szczególnymi zasoby wewnętrznymi, takimi jak: szczerość, czystość manifestowania uczuć, umiejętność dziwienia się, kreatywność i nade wszystko ufność w moc osób znaczących. Toteż koci bohaterowie w opowieściach, przedstawieni jako istoty bardziej bezbronne w porównaniu z ludźmi, mniejsze, słabsze, o których nie każdy pamięta w obliczu nagłej traumy, mogą szczególnie wzruszyć młodego

3 Seria Wojny Dorosłych - Historie Dzieci” Wydawnictwa Literatura to jak dotychczas 16 książek literatury faktu, wydanych częściowo w koedycji z Muzeum Powstania Warszawskiego. Celem serii jest przedstawienie trudnych historii dzieci z czasów wojny (II wojny światowej, czasów zsyłek na Sybir, ale też współczesnych konfliktów na Bliskim Wschodzie czy też wojny na Ukrainie, w Pakistanie) w przystępnej formie zbeletryzowanych opowieści. Więcej informacji patrz, wraz tytułami na stronie wydawnictwa: http://www.wyd-literatura.com.pl/atrybuty/wojny-doroslych-historie-dzieci.html (dostęp 20.12.2018)

4 Określenie „literatura antropologicznie wrażliwa” zostało użyte przez Danutę Świrszczyńską-Jelonek i odnosi się do literatury dla młodzieży tworzącej pole dla międzykulturowych spotkań rówieśników, pokazującej zmagania z codziennością nastolatków w różnych stronach świata (Świerczyńska-Jelonek, 2011). 
czytelnika. Doświadczenie lektur, w których poniewierani zwierzęcy i ludzcy bohaterowie cierpią z powodu głodu, zimna, zmęczenia, samotności, może stać się pomocne w uwrażliwianiu czytelników dziecięcych na niesprawiedliwość społeczną i krzywdę innych istot żyjących. Kocich bohaterów można postrzegać również (a może nade wszystko jednak) jako dzieci - upersonifikowanie dziecka, jako istoty bezbronnej, świadka tragicznych wydarzeń, z którego to perspektywy poznajemy fakty. Losy rówieśników mogą sprzyjać refleksji nad potrzebą dialogu z przedstawicielami różnych grup mniejszościowych, w obecnym, coraz bardziej zróżnicowanym kulturowo świecie.

Ważne jest jednak, że obie powieści kończą się pozytywnie, co może napawać czytelnika nadzieją i dawać mu wiarę w drugiego człowieka. Rodziny w pełnym składzie (oczywiście z kocimi bohaterami), dzięki pomocy życzliwych ludzi, powoli adaptują się do nowych warunków.

W powieści Kot Karima dwa plany wydarzeń, wspomnieniowy, związany z traumą, i aktualny, bezpieczny, osadzony w przestrzeni dalekiej od wojennej rzeczywistości, przeplatają się ze sobą nieustannie. Chłopiec o imieniu Karim za pomocą namalowanych przez siebie obrazków próbuje wytłumaczyć polskim kolegom, skąd przybył i co go spotkało. To samo czyni jego kot, tyle że wobec zwierzęcych lokatorów kamienicy i podwórka. Kot - uczestnik dramatycznych zdarzeń, jest nieustająco czujny i wystraszony, reaguje panicznym strachem na nic nie znaczące sytuacje życia codziennego. Boi się, że zapach dymu z komina może oznaczać pożar, a odgłosy burzy strzelanie. Jest przewrażliwiony w wyniku traumy, jakiej był uczestnikiem, wielokrotnie i od nowa przeżywa ucieczkę z podpalonego domu.

Biss opowiada losy swojej rodziny tak, jakby „[...] to było przed chwilą” (Bardijewska, 2016, s. 40). Nie godzi się, aby obrazek Karima nazywać tylko kawałkiem papieru „,- To nie jest kawałek papieru, to jest kawałek mojego życia! sapał Biss. [...] Była na nim noc i był dzień. Był upał i był mróz. Była niekończąca się droga i było niekończące się zmęczenie” (Bardijewska, 2016, s. 18).

Warto zatrzymać się przy takich fragmentach tekstu i porozmawiać z dziecięcym czytelnikiem na temat przyczyny, jakie stoją za niepokojącymi reakcjami bohatera. Cenne może być odwołanie się do priorytetów, którymi niewątpliwie dla małych dzieci będzie dom i rodzina. Fragmenty prozy wyraźnie akcentują, że nie da się zapomnieć o stracie najbliższych i domu, że wyciszanie emocji, przyzwyczajanie się literackich rodzin do nowego życia po traumie jest procesem powolnym.

Ponadto językowa strona tekstu oddaje niezmierzony niczym tragizm ludzi zmuszonych do nagłej ucieczki. Narracje Bissa do obrazków Karima przypominają 
marsz. Krótkie, nierozwinięte zdania, często nawet powtarzane po kilka razy same orzeczenia, sprawiają, że można zwizualizować słowa jako kroki zmęczonych, przerażonych i niepewnych swego losu ludzi. Kot opowiada tak, aby słuchający (inne zwierzęta/czytelnik) wczuli się w sytuację uchodźcy, który nieustannie maszerując, przestaje myśleć o czymkolwiek, czuje tylko strach, sam staje się wielkim strachem, przerażeniem, znużeniem. „Idą prosto w ciemność. Kroki, kroki, kroki. Odprowadza ich dym i woń spalenizny. Mama trzyma za rękę Karima. Karim trzyma Bissa. Babcia trzyma walizkę. Dnieje. Idą. Buty za butami, buty za butami, buty za butami. Torby, plecaki, toboły [...] wszystko w ciszy, bo granica, bo strażnicy, bo strach. Pną się coraz wyżej i wyżej. Zimno i coraz zimniej [...]” (Bardijewska, 2016, s. 19). „Patrzenie przez druty. Za drutami - droga. Za drutami - nadzieja. Po tej stronie tylko czekanie. [...] Który to już dzień, która to już noc?” (Bardijewska, 2016, s. 44).

Niewątpliwie uwrażliwianie na los drugiego człowieka, tego słabszego, zagrożonego, „nietutejszego”, jest tu założeniem podstawowym. Opowieści kota o wędrówce, kratach, uwięzieniu, pożarze, głodzie, strachu budzą milczenie i szacunek większości słuchających. Zdarza się jednak, że tak samo Karim jak i jego kot w nowym „domu” muszą sobie radzić z agresją „tutejszych”. Kilka poniższych cytatów oddaje dystans i niechęć do inaczej wyglądających bohaterów: „Rotwailery już od dawna ostrzyły sobie na niego zęby. Dlaczego? Bo kot, bo niebieski, bo cudzoziemiec, bo przybłęda. I co najważniejsze - bo nie rottweiler!” (Bardijewska, 2016, s. 64). Inny cytat: „,- Oboje sio stąd! Przybłędy! - warknęła. Biss posmutniał. Spieszyła na ratunek, chciał być wybawcą, a został [...] przybłędą. Który to już raz? - Nie jestem żadnym przybłędą. Jestem uchodźcą! [...] Osowiały Biss poczłapał do drzwi” (Bardijewska, 2016, s. 18). Jeszcze inny cytat: „,- Tu mają wstęp tylko bociany i żaby! [...] - Tak jest! Tylko sami swoi! - przytaknęła wiewiórka [...] Biss poczuł się nieswojo. - Tutaj trzeba być tutejszym! Fruwaj stąd!” (Bardijewska, 2016, s. 40).

Tego typu ksenofobiczne zachowania wzmacniają poczucie wyobcowania i niepewności bohaterów. Na początku opowieści jest dokładnie odwrotnie, niż jak pisał Tadeusz Kotarbiński: „ilekroć masz do czynienia z kimś innym, staraj się wejść w jego położenie, spojrzeć na sprawę z jego punktu widzenia. To daje zrozumienie cudzego stanowiska, wzbudza ducha tolerancji, osłabia natężenie konfliktów, zbliża ludzi” (Kotarbiński, 1986, s. 66). Słowa filozofa są niczym innym, jak wyznacznikami międzykulturowego uczenia się, które Bogusław Śliwerski określa „[...] procesem zachodzącym wówczas, kiedy w kontakcie z człowiekiem innej kultury staramy się zrozumieć jego specyficzny system orientacyjny - jego wartości, sposób myślenia i działania” (Śliwerski, 2005, s. 294) czy też między- 
kulturowego komunikowania się, które zgodnie z definicją Jerzego Nikitorowicza jest przekraczaniem granic własnej kultury, wchodzeniem na pogranicza ,[...] styki kulturowe po to, by wrócić bogatszym wewnętrznie i nabyć umiejętność porównywania w kategoriach nie lepsze-gorsze, ale w kategoriach inne, ciekawe, bodźcujące, zastanawiające” (Nikitorowicz, 2000, s. 100).

Początkowo nieufne, nawet arogancko nastawione zwierzęta, poznając historię „odmiennego” kota zaczynają postrzegać go jako bohatera. Od niechęci wynikającej z nieznajomości, przechodzą do akceptacji. „,- I bardzo dobrze, że abisyński! I bardzo dobrze, że z Syrii! Byłoby nudno, gdyby wszyscy byli stąd! Ja, dla przykładu, jestem światowa. Tak jest dużo ciekawiej!” (Bardijewska, 2016, s. 17). Inny zwierzęcy głos brzmi: „On jest bardziej tutejszy niż Ty!... I co z tego, że kiedyś mieszkał za morzem? Teraz mieszka tutaj” (Bardijewska, 2016, s. 29). Natomiast dla bociana opowieść o kraju zza morza (Syrii) to początek wspólnych doświadczeń, budowania porozumienia, co ptak pieczętuje słowami: „Jeśli chcesz, możesz tu zostać. W gnieździe jest mnóstwo miejsca - ofiarował mu gościnę bociek Patryk. W końcu byli krajanami zza morza” (Bardijewska, 2016, s. 39).

Odwołując się do psychologii rozwojowej dziecka w młodszym wieku szkolnym, kształtowanie się jego tożsamości osobowej i społecznej dokonuje się poprzez zauważanie w świecie dokoła różnic i podobieństw, nieustanne klasyfikowanie i zadawanie pytań o to, kim jestem. Stąd też zadaniem edukacji jest przeciwdziałanie dyskryminacji ze wzglądu na inność, tak więc przygotowywanie dziecka do odkrywania i rozumienia Innego, zaczynając od dostrzegania go w sobie (Nikitorowicz, 2005, s. 109).

Powyższe lektury o kocich bohaterach Kot Karima i Kot, który zgubił dom (ale też inne z podanej serii Wojny Dorosłych - Historie Dzieci), mogą okazać się pomocne przy okazji prezentacji dzieciom odmiennych grup wyznaniowych i etnicznych, jako książki kształtujące postawę ciekawości poznawczej i tolerancji dla inności. Można wykorzystać ich fragmenty do pracy nad niwelowaniem uprzedzeń wynikających z nieznajomości losów drugiego, do wizualizacji jego trudnej historii, jak i długotrwałego procesu wczuwania się w jego sytuację, wyobrażania jej odczuć.

Ponadto omawiane dwie lektury mogą być pretekstem do dyskusji z dziećmi o użyteczności w życiu społecznym granic, murów, mostów. Dzieci na pewno słusznie zauważą, że granice i mury są „,wymysłem” świata dorosłych. W świecie dziecka nie ma granic, nie ma podziałów na tutejszych i przybłędów, na lepszych i gorszych, tak samo jak nie ma rzeczy, o które można nie zapytać. Dziecięce postrzeganie świata (wspomniana ufność, ale też bezpośredniość, prostolinijność) odkrywa hipokryzję i manipulację, cechujące świat licznych dorosłych. Wrażliwe- 
mu dziecku szczególnie trudno jest zrozumieć, dlaczego palą się domy, dlaczego ludzie wytykają siebie palcami, krzyczą 5 .

Jeszcze jedna kwestia, której nie można pominąć przy lekturach o „kocich” (oczywiście nie tylko) uchodźcach, jest pewna gorzka myśl - to od nas zależy życie owych imigrantów w danej chwili, my również możemy dopisać dalszy ciąg ich losów.

Także opowieść o kocie Leonie, z powieści Grażyny Ruszewskiej Leon i kotka, czyli jak rozumieć mowę zegara (2004), w którego życie wkracza przygarnięta z ulicy kotka, jest wzruszającą powieścią o trudnych początkach rodzącej się przyjaźni, o poskromieniu w sobie zazdrości, o zmianach, które często okazują się dobre, bo wymagają od nas wyjścia z rutyny, skostniałych nawyków podszytych stereotypami. „Świat nie był taki sam, jak przed godziną”, a Leon razem z dziecięcym czytelnikiem musi odnaleźć się w nowej sytuacji, wobec zagubionej istoty w jego domu'.

Podobnie nieufność wobec siebie z racji przynależności do innych ras oraz powolne, cierpliwe oswajanie siebie nawzajem miało miejsce w książce Danuty Parlak Pan Mruczek i mysia rodzina (2009). „Najpierw obaj zachowywali pełne rezerwy milczenie [...], potem zaczęli wymieniać pozdrowienia i niezobowiązujące uwagi o pogodzie, bo nie wypada się nie odzywać. Z czasem doszło do pewnego rodzaju zażyłości. Pan Mysz dzielił się troskami życia rodzinnego [...]” (Parlak, 2009, s. 42).

5 W swoim innym tekście mającym ukazać się z datą 2019 r. w „Kwartalniki Pedagogicznym”, na przykładzie powieści Jarosława Mikołajewskiego Wędrówka Nabu (2016) poruszam między innymi kwestię w kontekście współczesnego kryzysu uchodźczego, symbolicznej wędrówki dziecka (ufnego, dobrego, nie stawiającego murów) poprzez świat skarżony ręką dorosłego, gdzie króluje wojna, kolczaste druty, mury, szyderczy śmiechu i pytam, czy możliwe jest oceanie jego dzieciństwa. Wędrówka Nabu

6 Leon i kotka, czyli jak rozumieć mowę zegara Grażyny Ruszewskiej znajduje się w podręczniku do klasy pierwszej szkoły podatkowej Odkrywam siebie. Ja i moja szkoła tyle że w formie nieprzemyślanego streszczenia, co odbiera w mojej opinii opowieści wartość zarówno edukacyjną jak i artystyczną. Książka, która została wyróżniona w konkursie IBBY „Książka Roku 2004” w kategorii tekst i ilustracja oraz została wpisana na prestiżową listę „Białych Kruków” prowadzoną przez Międzynarodową Bibliotekę Książek dla Dzieci w Monachium, została, używając języka kolokwialnego, spłaszczona do konsystencji niestrawnej papki, gdzie przesłanie jak i poziom ilustracji zupełnie nie oddają atmosfery i mądrości oryginalnej opowieści. Kwestia książki wydaje się o tyle ciekawa, że wywołała burzę wśród, co się chwali, świadomych rodziców, którzy to dali wyraz swemu zatroskaniu, pytając się o jakość kontroli zawartości podręczników. Wypowiedzi dotyczyły „[... ] jak rozwijać inteligencje wielorakie przy takim potraktowaniu porządnej książki” czy też „Czy takie oswajanie pierwszoklasisty z tekstem literackim ma zbudować nasze »kreatywnie«, myślące społeczeństwo?”. Porównaj: http://pozarozkladem.blogspot.com/2013/05/jak-wychowac-pogowkow. html [dostęp: 18.12.2018]. 
Opisana tu scena przywołuje na myśl moment oswajania, tworzenia więzi między lisem a Małym Księciem („,- Trzeba być bardzo cierpliwym. Na początku siądziesz w pewnej odległości ode mnie, ot tak, na trawie. Będę spoglądać na ciebie kątem oka, a ty nic nie powiesz. Mowa jest źródłem nieporozumień. Lecz każdego dnia będziesz mógł siadać trochę bliżej [...]” (de Saint-Exupery, 2008, s. 62).

$\mathrm{Z}$ czasem okazuje się, że kwestia rasy nie ma znaczenia w przypadku rozwijania nici porozumienia. Mysia rodzina zaprzyjaźnia się z kotem, co ma miejsce w szczególnej przestrzeni - w antykwariacie jako miejscu spotkania i wymiany mądrości myśli ksiąg wielu pokoleń. Ta szczególna, co należy podkreślić, przestrzeń przytulnego, sprzyjającego dialogowi antykwariatu dodatkowo została w opowieści skontrastowana z bezduszną, a nawet wrogą przestrzenią supermarketu. Tu pod refleksję można poddać nasuwające się skojarzenie z typem tożsamości „super market”, wyłonionej przez Zbyszko Melosika, jako jednej z wielu tożsamości powstających w kontekście społeczeństwa globalnego. Cytując autora: „W społeczeństwie konsumpcji konstruowana jest tożsamość typu supermarket, oparta na przekonaniu konsumenta, że można konstruować się i rekonstruować w sposób wolny i dowolny - wybierając z kulturowych ofert (rzeczywistość jawi się nam jako jeden wielki MacroCash - wszystko jest dostępne natychmiast i wszystko można wrzucić do koszyka... swojej tożsamości”) (Melosik, 2003, s. 21).

Jedna z bohaterek opowieści, co stanowi istotę fabuły, traci w supermarkecie, w sensie dosłownym - siebie, gubi swoją tożsamość. Mysz (personifikacja młodego człowiek), zachłysnąwszy się natychmiastową dostępnością ofert wokoło, zamienia się w monstrum. I gdyby nie przyjaźń (z kotem), związana z nią odpowiedzialność za to, kogo oswoiliśmy, gdyby nie więzi stworzone przed przykrym incydentem, supermarket wchłonąłby bohaterkę, która przecież tylko na krótką chwilę się w nim „zapomniała”.

Mały Książę w momencie kryzysu spotkał Lisa, który prosił go, aby nie zapominał, że: „,- Poznaje się tylko to, co się oswoi... Ludzie mają zbyt mało czasu, aby cokolwiek poznać. Kupują w sklepach rzeczy gotowe. A ponieważ nie ma magazynu z przyjaciółmi, więc ludzie nie mają przyjaciół. Jeśli chcesz mieć przyjaciela, oswój mnie!” (de Saint-Exupery, s. 62). Toteż rozmawiając z dzieckiem o książce Danuty Parlak Pan Mruczek i mysia rodzina, warto przytoczyć powyższe słowa z powieści Saint-Exupery’ego i następnie zapytać dziecko, co stało się z myszką w supermarkecie, co sądzi o opisanej przyjaźni myszy się z kotem, jak rozumieją, czym jest odpowiedzialność.

Treści poddanych analizie powieści bliskie są regułom nauki współbycia, która jest czymś więcej niż współpracą czy współdziałaniem. Współbycie stanowi taką relację interpersonalną, w której, jak pisała Bronisława Dymara: „[...] akceptacja 
dla pewnych wspólnych idei, celów, przedsięwzięć, kierunków myślenia bądź uświadomienie sobie przez partnerów dialogu wspólnoty emocjonalnej, intelektualnej i duchowej - wyzwala poczucie sensu, satysfakcji i radości bycia z tym Innym. Relacje, o których tu mowa, tworzą życzliwą przestrzeń międzyosobową, w której unika się pośpiechu, powierzchowności i wszelkich imitacji. Pozostający w tak wartościowym dialogu zarówno dorośli, jak i dzieci uczą się wnikliwości poznawczej i przetwarzania wiedzy w mądrość” (Dymara, 2013, s. 219).

Jeszcze w jednej powieści - Kotce Brygidy (2007), adresowanej do nieco starszego czytelnika, autorka Joanna Rudniańska korzysta z konwencji wprowadzenia kota jako powiernika, współtowarzysza, opiekuna dzieci. Kotka Brygidy opowiada o II wojnie światowej z perspektywy dziecka, gdzie kotka należąca do żydowskiej dziewczynki pozwala na ocalenie pamięci o jej losach. Problem pamięci w tej powieści łączy się z kształtowaniem tożsamości bohaterki - Heleny, a jak wiemy, pamięć, zarówno jednostek, jak i zbiorowości, jest istotą tożsamości. Jak zauważyła Barbara Szacka, bez świadomości zakorzenienia w czasie i posiadania własnej przeszłości poszczególne jednostki oraz całe grupy nie są w stanie normalnie funkcjonować (Szacka, 2006, s. 47-48). Podobnie twierdził Mauricea Halbwachs, pisząc, iż do zachowania tożsamości danej grupy niezbędne jest posiadanie przez nią pamięci o własnej przeszłości (Halbwachs, 1969).

Helena jest dziewczynką mieszkająca po aryjskiej stronie, która dzięki kotce staje się strażniczą pamięci o ofiarach wojny i strażniczą świadomości istnienia dziedzictwa kulturowego jej miejsca zamieszania (pamiętała jeszcze, jak z drzewa morwy obserwowała trzy świątynie stojące niemalże obok siebie - cerkiew, kościół i synagogę, jak uważała, że w każdym z tych miejsc mieszka jeden Bóg i że to jest Trójca Przenajświętsza). Jak pisze Jerzy Nikitorowicz świadomość i potrzeba kontynuowania dziedzictwa kulturowego powinna być obowiązkiem i pierwszą z zasad postępowania. Okazanie szacunku dla przodków to wartość, dzięki której możemy kreować własny system wartości. Może ona funkcjonować poprzez przekaz w procesie wychowania, jak również być przechowywana w instytucjach chroniących świadectwa historii i kultury. Ma to na celu kształtowanie pożądanych postaw wobec dorobku przodków, wywoływanie doznań emocjonalno-estetycznych oraz zachowanie ciągłości kulturowej grup (Nikitorowicz, 2009, s. 226-227). Żydowscy koledzy Helenki nagle znikają, a zamiast nich pojawia się kotka, której właścicielka - dziewczynka o imieniu Brygida, niemalże rówieśnica Helenki trafia do getta. Dziewczynki nie zdążyły się zobaczyć, poznać, jednakże Helenka dzięki kotce wyobraża sobie Brygidę, rozmyśla o niej, a nawet zaczyna za nią tęsknić. Kotka jest nie tylko powiernicą dziecięcych trosk (element magiczny, gdyż Helena wierzy, że kotka z nią rozmawia), przyjaciółką, o którą szczególnie 
należy się troszczyć, ale istotnym znakiem nieznajomej Brygidy, jej ocalałą częścią, a jednocześnie częścią wielkiego narodu, jego tradycji, o czym Helena w dalszym swoim życiu (o czym jest powieść) będzie pamiętała.

Niezwykle wzruszająca i jednocześnie dająca możliwość wielu interpretacji jest jedna z końcowych scen powieści, w której to Helena, w podeszłym już wieku, z perspektywy kresu swojego życia, przygląda się odnalezionej fotografii, na której widzi pierwszy raz Brygidę tulącą kotkę. Helena spostrzega, że oczy kotki są podobne do oczu Brygidy. Dorosła już Helena wie, że ocalenie podobizny jest ocaleniem pamięci o zmarłym.

\section{ZAKOŃCZENIE}

Literatura piękna jest niewyczerpanym źródłem wzorców moralnych, jak również rozwijania zdolności reagowania w obliczu sytuacji trudnych (literatura jako środek zaradczy). W procesie wspierania rozwoju małego dziecka dobrze jest sięgać po przypowieści, baśnie, bajki, a więc teksty, które określić można mianem „mądrościowych” (Tokarska, 2008; Bettelheim; Kraków, 1985).

Moja propozycja dotyczyła pracy z lekturami z kocimi bohaterami w kontekście problematyki odmienności społeczno-kulturowej, podjęcia z ich pomocą prób uwrażliwiania na drugiego człowieka (często „Innego”, uchodźcy, ofiary wojny), zauważania potrzeby pojednania, więzi, wspólnoty, przy postawie pokory, życzliwości, analizowania siebie.

Postać kota w analizowanych testach została wykorzystana do praktycznych celów, stała się poetyckim chwytem budzącym pozytywne skojarzenia, sprzyjającym kształtowaniu u dzieci wartości i uczuć wyższych. Kociaki jako dziecięcy ulubieńcy, a tu bohaterowie literaccy często w roli opiekunów ludzi, których mięciutkie sylwetki i mruczenie (te atrybuty kojarzono z bezpieczeństwem) zna każde dziecko już z pierwszych tekstów literackich jakimi są kołysanki, pomagają w urzeczywistnianiu wartości lektury, przekazie treści istotnych, takich jak: rozwijanie empatii, wrażliwości, budzeniu ciekawość wobec innych kultur.

Omawiana proza może pomóc w dyskusji z dzieckiem na trudne dla niego tematy (wojna, utrata domu, uchodźstwo, wykluczanie grup mniejszościowych, nietolerancja, jak również odpowiedzialność za drugą osobę lub stworzenie pozostające pod naszą opieką). Rodziny kotów zabrały je ze sobą, pomimo zawieruchy wojennej, co czyni te opowieści przykładami literatury eksponującej znaczenie przyjaźni i więzi między człowiekiem a zwierzęciem, literatury, która sprzyja nauce odpowiedzialności dziecka. Dzieci wychowane na takich lekturach mają 
szansę wyrosnąć na wrażliwych, empatycznych dorosłych. Dowiadują się również, że więzi buduje się poprzez uważne słuchanie, poznawanie, szukanie wspólnoty doświadczeń.

Lektury odwołują się do założeń edukacji międzykulturowej jako procesu dialogu kultur, kształtowania postaw wyrzekających się poczucia wyższości kulturowej na rzecz dialogu i wymiany wartości. Postrzegam je również jako materiał pomocny przy rozwijaniu, zgodnie z duchem edukacji międzykulturowej, kompetencji emocjonalnych, zwłaszcza empatii, która jest przecież podstawowym składnikiem zachowań prospołecznych oraz moralności ${ }^{7}$. Carolyn Saarni przekonuje, że świadomość uczuć to kluczowy składnik kompetencji emocjonalnych, dalej jest umiejętność dostrzegania emocji przeżywanych przez innych, umiejętność empatycznego angażowania się w emocjonalne doświadczenia innych, co z kolei staje się najważniejszym elementem wspomagania tworzenia się więzi międzyludzkich (Saarni, 1999, s.102).

\section{Bibliografia}

Baluch, A. (2009). Koty w formach prostych literatury. Guliwer, 3.

Bettelheim, B. (1985). Cudowne i pożyteczne: o znaczeniach i wartościach baśni. T. 1 i 2. Kraków: WAB.

Cooper, J.C. (1998). Zwierzęta symboliczne i mityczne. Poznań: Rebis.

Dymara, B. (2013). Współbycie interpersonalne dzieci i dorosłych jako fenomen i zadania edukacji. Bliżej pedagogiki współbycia. W: E. Ogrodzka-Mazur, U. Szuścik, J. Oleksy (red.), Edukacja małego dziecka. T. 4. Cieszyn-Kraków: Impuls.

Halbwachs, M. (1969). Społeczne ramy pamięci. Wstęp i przekł. M. Król. Warszawa: PWN. Kopaliński, W. (1985). Słownik mitów i tradycji kultury. Warszawa: PIW.

Kopaliński, W. (1990). Słownik symboli. Warszawa: PIW.

Kotarbiński, T. (1986). Medytacje o życiu godziwym. Warszawa: Wiedza Powszechna. Madalińska-Michalak, J., Górska R. (20012). Kompetencje emocjonalne nauczyciela. Warszawa: Wolter Kluwer.

Nikitorowicz, J. (2000). Spotkanie i dialog kultur - wymiar edukacji międzykulturowej. W: T. Pilch (red.), O potrzebie dialogu kultur i ludzi. Warszawa: Wydawnictwo Akademickie Żak.

7 W książce Kompetencje emocjonalne nauczyciela autorstwa Joanny Madalińskiej-Michalak i Renaty Górskiej (Warszawa 2012) autorki przedstawiają ćwiczenia wypracowane w ramach projektu EL4VET, który był realizowany w ramach programu LLP Leonardo da Vinci w latach 2010-2012, zaadoptowane do polskiej szkoły, których realizacja ma pomoc nauczycielom we wdrożeniu do praktyki zaleceń różnych autorytetów w dziedzinie edukacji emocjonalnej. Na proponowany model kompetencji emocjonalnych nauczycieli składają się następujące atrybuty: empatia, entuzjazm, przebaczenie, optymizm, władza wychowawcza, budowanie relacji interpersonalnych, pewność siebie, sprawiedliwość społeczna, zaufanie, znajomość kultury uczniowskiej. 
Nikitorowicz. J. (2005). Kreowanie tożsamości dziecka. Gdańsk: GWP.

Nikitorowicz. J. (2009). Edukacja regionalna i międzykulturowa. Warszawa: Wydawnictwa Akademickie i Profesjonalne.

Piaget, J. (2006). Jak sobie dziecko wyobraża świat. Warszawa: PWN.

Plopa, M. (2008). Psychologia rodziny. Teoria i badania. Kraków: Impuls.

Saarni, C. (1999). Kompetencja emocjonalna i samoregulacja w dzieciństwa. W: P. Salovey, D.J. Sluyter (eds.), Rozwój emocjonalny a inteligencja emocjonalna. Problemy edukacyjne. Tłum. M. Karpiński. Poznań: Rebis.

Slany, K. (2009). Kot jako psychopompos we współczesnej literaturze dziecięcej. Guliwer, 3.

Szary, A. (2009). Kot jaki jest każdy widzi. Guliwer, 3.

Śliwerski, B. (2005). Współczesne teorie i nurty wychowania. Kraków: Impuls.

Świerczyńska-Jelonek, D. (2011). Baśniowość i antropologiczna wrażliwość współczesnej obyczajowej i psychologicznej literatury młodzieżowej. W: G. Leszczyński (red.), Sztuka dla dziecka. Tradycja we współczesności. Poznań: Centrum Sztuki Dziecka.

Szacka, B. (2006). Czas przeszły, pamięć, mit. Warszawa: ISP PAN.

Tokarska, U. (2008). Wybrane strategie wykorzystania tekstów literackich w narracyjnych oddziaływaniach profilaktycznych. W: B. Janusz, K. Gdowska, B. de Barbaro (red.), Narracja. Teoria i praktyka. Kraków: Wydawnictwo UJ.

http://www.wyd-literatura.com.pl/atrybuty/wojny-doroslych-historie-dzieci.html. http://pozarozkladem.blogspot.com/2013/05/jak-wychowac-pogowkow.html.

\section{Literatura piękna:}

Bardijewska, L. (2016). Kot Karima i obrazki. Łódź: Wydawnictwo Literatura.

de Saint-Exupery A. (2008). Mały Ksiq̨żę. Warszawa: Wydawnictwo Muza.

Mikołajewski, J. (2016).Wędrówka Nabu. Kraków: Wydawnictw Austeria.

Nowak, E. (2016). Kot, który zgubił dom. Warszawa: Egmont.

Parlak, D. (2009). Pan Mruczek i mysia rodzina. Warszawa: BIS.

Rudniańska, J. (2007). Kotka Brygidy. Lasek: Wydawnictwo Pierwsze.

Ruszewska, G. (2004). Leon i kotka, czyli jak rozumieć mowę zegara. Łódź: FRO9. 


\section{KOMUNIKATY - RELACJE}


